\title{
Zimbabwean History: Becoming Complex
}

\author{
Review of Brian Raftopoulos and Alois Mlambo, eds. \\ Becoming Zimbabwe: A History from the Pre-Colonial Period to 2008 \\ Harare and Johannesburg: Weaver and Jacana, 2009 \\ pp. v-xxxiv, 260 \\ ISBN: 978-1-77922-083-7
}

\begin{abstract}
David Moore
Department of Anthropology and Development

University of Johannesburg, Box 524, Auckland

E-mail:dbmoore@uj.ac.za
\end{abstract}

On the back cover of Becoming Zimbabwe: A History from the Pre-Colonial Period to 2008 this reviewer's blurb says it is "a profoundly new history that tears apart all of the old certainties". That might be misleading: if the 'certainties' referred to are Zimbabwe's ruling party's versions of its truths, then any reader with an iota of objectivity would not find it hard to deconstruct them. It's not too difficult to refute the Zimbabwe African National Union - Patriotic Front's (ZANU-PF) claim that Zimbabwe's modern war(s) of liberation (i.e. 'Chimurenga 2' in the sixties and seventies and 'Chimurenga 3' of the past decade) were all about restoring the land to its rightful occupiers, nor would it be difficult to disprove tales of a 'Zvimba Dynasty' that has the royal heritage of the Zimbabwe's current president going back centuries' ${ }^{1}$.

It is a tougher task to revise the more subtle historical beliefs beneath the turmoil of Zimbabwe today; there long before the current crisis. It is a more profound project to tear down and rebuild the intellectual foundations on which ZANU-PF has erected its ephemeral interpretations of the past to service its (hopefully equally fleeting, but already 30 years long) current hold on power. Becoming Zimbabwe has begun that process substantially.

It chips away at the old historical narratives and historiographical epistemologies reifying the pre-colonial and colonial contexts, the tensions of tribe, the contradictions of class, and the legacy of the liberation war, that constitute a complex matrix upon which the more propagandistic blandishments of contemporary Zimbabwe's tragedy rest. 
The accepted verities of history in Zimbabwe structure even anti-ZANU-PF discourses, not to mention 'a-political' versions of history. Becoming Zimbabwe is a long-awaited start at their dismantling.

Becoming Zimbabwe has also started a second, more overtly political project, inclusive of but also beyond a teleological reading that could have some readers believing there is a (neo- Nationalist) mission behind the title. (This is indicated in the introduction entitled "The Hard Road to Becoming National", which is so hard the end is not really in sight. Thus the editors' conclusion, befitting historians, tapers off with a call for better history - better than offered by truth commissions, at least! - which might somehow lead to an improved nation[alism]). Becoming Zimbabwe is not a book simply occasioned by the rise of an opposition party worth ZANU-PF worrying about, but there is a deep sense of democratic hope underpinning this historical omnibus, an aspiration that is epitomised by the Movement for Democratic Change (even in its two versions) and the civil society activism alongside it, spurring movement towards civic nationalism at the end of the tunnel.

Thus Becoming Zimbabwe surveys Zimbabwe's very longue durée (long, indeed: Gerald Mazarire's stunning 'Reflections on Pre-Colonial Zimbabwe starts at around 850) with an openness of inquiry that prefigures a truly democratic dispensation while at the same time being very much aware that, as Bill Freund has put it, "in order to be meaningful, discussions of democratic prospects in [Zimbabwe or anywhere] ... require a real grasp of the historically generated and limited situation ... it is this dimension, this sense of the determined and the possible, to which historians in particular can make a crucial contribution ${ }^{2}$."

One cannot say that this book is burdened by the weight of history, because it is bursting with an effort to chart a history pregnant with a meaning saying 'the current tragedy did not have to happen: it was not predestined'.

Yet simultaneously none of the excellent historians in Becoming Zimbabre would dare say Zimbabwe's present conjuncture is a tabula rosa on which a new history can be made, nor that the current imbroglio is not to some extent structured. Like all good social scientists - and this book is informed by a sociological sensibility combined with a political economy bias - the contributors are contesting the binaries of structure and agency that pervade any halfway interesting study of a society's past and present.

In these ways, then, Becoming Zimbabwe is both an intense survey of just

2 Bill Freund, 'The Weight of History: Prospects for Democratisation in South Africa', Jonathan Hyslop, ed., African Democracy in the Era of Globalisation Johannesburg: University of the Witwatersrand Press, 1999, p. 434. 
about all the history and social science scholarship on Zimbabwe written to date, as well as an attempt - sometimes explicit, at others between the lines - to break out of those bounds. On the 'survey' front the range starts off by confronting slanted pre-colonial histories written seemingly to justify contemporary configurations of ethnic power or their mirror images. The seminal qualities of Mazarire's tour de force "Reflections on Pre-colonial Zimbabwe, c.850 - 1880s" must again be emphasised; not only for setting new angles on empirical research for that era but for establishing new lenses for the "sagas of political intrigue and competition" (p. 16) that now as well as then blend military strata with political and ideological castes in struggles for clientelism (Mazarire uses the notion objectively based on his study of what could be called the nyai class's move into spaces of power during times of transition: it is not a pre-disposition imposed by neo-Weberian political scientists) and re-aligned articulations of power leading to altered statist organisations. Perhaps the arrival of the Ndebele should be known for altering the complex nyai system more than their previously assigned role of the first oppressor 'nation': Mazarire - as well as Sabelo Ndlovu- Gatsheni in the next chapter on colonial encounters - starts the inquiries into the Ndebele place in Zimbabwe's history, the opening up of which is a pivotal part of the process of inventing a new Zimbabwe historiography.

Of course, part of that apertura leading to a new Zimbabwean history consists in the debates among Ranger, Cobbing and Beach about whether or not the 'first Chimurenga' was really a united struggle. Ndlovu-Gatsheni's "Mapping Cultural and Colonial Encounters, 1880s - 1930s" summarises those arguments adeptly (and Ranger's unity thesis does not come off too well).

Ndlovu-Gatsheni also starts off on a path promising more complexities, unevenness, complicity, contestations of too easy binaries, mimicry, syncretism, hybridities, negotiations, alienations - and even white's efforts to 'ndiginise themselves' (pp. 48, 68, 40) - than one chapter can hope to condense, if such a task is possible at all. Co-editor Alois Mlambo's contribution on the 1940s to the 1960s serves as ballast to such radical uncertainty as it surveys the more definite terrain of class differentiation amidst the development of a coherent ideology - stymied only by the intransigence of the Smithian rearguard, which sealed an equally interesting split between liberal and reactionary whites (still left too unexplored in this and all Zimbabwean histories) that led to war. Joseph Mtisi, Munyaradzi Nyakudya, and Teresa Barnes team up to write the next two chapters dealing with society, economy and war during the period of white reaction and black liberation. They start by accepting Jeffrey Herbst's strikingly American notion that the Rhodesian Front practised 'socialism for the whites' (what ever happened to the idea of 'state capitalism'?), but go on to 
tackle the theme of 'nation' among both blacks and whites with considered complexity amidst the African nationalist struggle, as progress towards majority real was finally Manifested in 1980. The authors' comprehensive sources, ranging from a vast array of University of Zimbabwe history and political studies theses, assiduously cultivated official archives, oral history, and mastery of all the secondary literature one could imagine, reveals the high standards of the Zimbabwean intellectual industry.

Deftly weaving the political economy of sanctions and their busting with the demands of white workers for the 'good life', and the contradictory efforts to win the 'hearts and minds' of Africans while simultaneously practicing scorched earth policies, the march through the political economy of UDI leaves no doubt that antiquated beliefs about 'democracy', defined mostly by race but partially by merit, wealth and property, could not last long even if protected by an impressive - but expensive - war machine. In that context, perhaps it is not surprising that the history of the liberation war charted by the three authors is more interesting for the tensions of class, ideology, gender, generation and ethnicity illustrated from within the nationalists, than their progress towards a united nationalism or a victory which was more or less foretold. Continuing Becoming Zimbabwe's tradition of mastering the sources, James Muzondidya's "From Buoyancy to Crisis" charts the rise and fall of ZANU-PF's efforts to consolidate the tenuous hold on power it gained in 1980 by blending a belated mode of welfarism (why Zimbabwe did not have to adopt structural adjustment policies until the 1990s while the rest of Africa was pushed into them much earlier is a question not asked here or elsewhere; but is probably intimately tied in with Cold War and southern African regional politics) with increasingly excessive coercive capacity. Structural adjustment policies in the nineties, combined with less than enthusiastic efforts to work out the land issue and to create a black bourgeoisie and middle class with a base in production rather than rent-seeking led ZANU-PF down the road to the crisis of the past decade with which we think we are all too familiar. Brian Raftopoulos's deftly crafted final chapter, however, blends all the elements of those years into a complex whole that goes beyond the expected. From debates about 'fast-track' land reform and the 'national democratic revolution', to the disappointments of South African-led 'mediation, to the economic meltdown epitomised by unimaginable rates of hyperinflation leading to the complete disappearance of Zimbabwe's dollar, Raftopoulos ability to blend scholarly activism with academic rigour unmatched in the ivory towers serves historians and political economists well.

Such a nuanced approach cannot allow the dialectic between authoritarian nationalism and deep new forms of democracy to be resolved. Becoming 
Zimbabwe's conclusion is about as tentative - if not as stalemated - as the 'government of national unity' with which the decade ended. Raftopoulos has remarked lately that some of the reasons for Zimbabwe's impasse - perhaps as much intellectual as political and economic - are rooted in a sharp dichotomy between a historical and almost non-political notions of human rights and 'good governance' so pervasive in opposition and donor circles now, and a harsh, economistic idea of 'political economy' (combined, one might say, with a crude nationalism built on narrow notions of sovereignty and the importance of 'the land') deeply entrenched in the older generation of Zimbabwe's intelligentsia and political class ${ }^{3}$. Becoming Zimbabwe goes a good way to delivering on its promise to move us away from these debilitating binaries. If it becomes a set-university text and also informs secondary school curriculum restructuring, Zimbabwe could well be on the road to getting out of its impasse, which, as the chapters in this extremely thought-provoking book show, is deeper and more complex than ever imagined.

3 See Brian Raftopoulos, "The Zimbabwean Crisis and the Challenges for the Left', Journal of Southern African Studies, 32, 2, June 2006, pp. 203-17, for an early expression of this concern. 